\title{
The Effects of Hypothalamics Lesions in Genetically Diabetic Mice*
}

\author{
D. L. Coleman and K.P. Hungmei
}

The Jackson Laboratory**, Bar Harbor, Maine USA

Summary. Genetically diabetic $(d b / d b)$ and normal $(+/+)$ mice were lesioned in the ventromedial nucleus by either gold thioglucose or electrocauterization. The normal mice responded typically to either of these treatments by becoming hyperphagic, obese, and by exhibiting moderately elevated plasma insulin concentrations coupled with near normal blood sugar concentrations. In diabetic mice, destruction of the ventromedial nucleus prevented the development of severe hyperglycemia and had a therapeutic effect in those mice with established, but moderate, hyperglycemia. Hyperphagia and rapid accumulation of adipose tissue continued unabated as expected. Regranulation of the $\beta$-cells of the endocrine pancreas was associated with the maintenance of blood sugar at normal concentrations. The marked improvement of the diabetic aspects of this syndrome in mice lends support to the hypothesis that the primary defect in diabetic mice may involve a defective hypothalamus, particularly in the regions of the satiety centers.

Effets de lésions hypothalamiques chez la souris génétiquement diabétique

Résumé. Le noyau médioventral de la région hypothalamique de souris présentant un diabète génétique $(d b / d b)$ et de souris normales $(+/+)$ a été lésé par l'administration d'aurothioglucose ou par électrocautérisation. Les souris normales répondent de façon typique à l'un ou lautre de ces traitements en devenant hyperphagiques, obèses, et en montrant une élévation modérée de l'insulinémie tout en gardant des taux de glucose sanguins voisins de la normale. La destruction du noyau médioventral chez la souris diabétique empêche le développe. ment d'une hyperglycémie sévère et a un effet thérapeutique chez les souris modérément hyperglycémiques. L'hyperphagie et l'accumulation rapide de tissu adipeux continuent à une cadence soutenue, comme prévu. La regranulation des cellules $\beta$ du pancréas endocrine est accompagnée de taux de glucose sanguin normaux. L'amélioration prononcée des symptomes diabétiques dans ce syndrome chez la souris renforce l'hypothèse suivant laquelle le défaut primaire chez la souris diabétique implique une insuffisance hypothalamique, en particulier dans la région des centres de la satiété.

Folgen hypothalamischer Läsion bei hereditör diabetischen Mäusen

Zusammenfassung. Bei hereditär diabetischen $(d b / d b)$ und normalen $(+/+)$. Mäusen wurde der ventromediale Kern des Hypothalamus entweder durch Goldthioglucoseinjektion oder durch Elelktrokauterisierung zerstört. Auf diese Behandlung reagierten normale Mäuse wie erwartet mit Hyperphagie, wurden fettsüchtig und zeigten bei normalen Blutzuckerkonzentrationen erhöhte Plasmainsulinkonzentrationen. Bei den diabetischen Tieren verhinderte der Eingriff den weitern Anstieg der Blutzuckerkonzentration und hatte bei mäßig hyperglykämischen. Tieren eine Senkung des Blutzuckerspiegels zur Folge. Gleichzeitig blieb die für die $a b / d b$ Mäuse charakteristische Hyperphagie bestehen und führte wie bei unbehandelten $d b / d b$ Tieren zur Fettsucht. Im Pankreas wurde nach Setzen der hypothalamischen Läsionen eine Regranulation der B-Zellen beobachtet. Die deutliche Verbesserung der diabetischen Stoffwechsellage durch Zerstörung der ventromedialen Kerne des Hypothalamus läßt den Schluß zu, daß der primäre zur Entwieklung des Syndroms führende Defekt diese Strukturen des Zentralnervensystems betrifft.

Key-words: Hereditary diabetes, mouse, lesions, ventromedial nucleus, satiety center, hypothalamus, gold thioglucose.
Our studies of mice homozygous for the gene diabetes ( $d b$ ) suggest that the primary defect may lie in the hypothalamus. Diabetic mice are hyperphagic, obese, functionally sterile with atrophic gonads and accessory structures, hyperinsulinemic $[2,3,4]$ and are extremely sensitive to heat and cold. The higher than normal level of circulating insulin seems particularly important in the development of mouse diabetes because it is the earliest observable symptom, occurring at 2 weeks of age and persisting until $12-13$ weeks at

* Supported by NIH Research Grant CA 05873 from the National Cancer Institute, by NIH Research Grant HD 00468 from the National Institute of Child Health and Human Development, by an allocation from NTH General Research Support Grant FR 05545 from the Division of Research Resources to the Jackson Laboratory, and by allocations from the Aaron E. Norman Fund and the Edwin S. Webster Foundation.

** The principles of laboratory animal care as promulgated by the National Society for Medical Research are observed in this laboratory. which time it drops to near normal levels. Hyperinsulinism in these mice may be a consequence of hyperphagia which stimulates the pancreas to secrete excessive amounts of insulin to handle the increased carbohydrate intake. However, hyperinsulinemia occurs before hyperphagia in rats that have received lesions in the ventromedial nuclei (VMN) of the hypothalamus [5]. These nuclei include the satiety centers that function to inhibit the feeding centers in the lateral hypothalamus [1]. A recent study [6] has suggested that uninhibited functioning of the lateral hypothalamus may result in direct neurogenic stimulation of the pancreas to secrete insulin, thereby causing the hyperphagia.

Recently we studied the effects of parabiosis of normal with diabetic mice and observed death of the normal partner apparently by starvation within 2 to 4 weeks after surgery [4]. Our explanation of this observation is that normal and diabetic mice produce a circulating satiety factor to which diabetic mice are una- 
ble to respond. In the parabiotic situation this satiety factor enters the circulation of the normal partner, acts on its functional satiety centers, and inhibits eating drive. If the abnormal satiety center of diabetic mice could be destroyed, amelioration of the diabetes might ensue. This paper describes the effects of destruction of the ventromedial nucleus either by chemical means (gold thioglucose) or by direct electrolytic lesioning in both normal and diabetic mice.

\section{Materials and Methods}

The diabetic mice used in these studies came from two independently derived stocks. In the experiments involving electrolytic lesioning, inbred mice of the C 57 $\mathrm{BL} / \mathrm{KsJ}-d b$ strain were used whereas in the experiments involving gold thioglucose (GTG), non-inbred diabetic mice from a balanced color stock (DBM) were used. We derived the DBM stock from offspring of a cross between a mouse homozygous for the misty $(\mathrm{m})$ coat color $(\mathrm{C} 57 \mathrm{BL} / 6 \mathrm{~J}-\mathrm{m} / \mathrm{m})$ and a black mouse heterozygous for the diabetes allele $d b \quad(\mathrm{C} 57 \mathrm{BL} / \mathrm{KsHu}$ $d b /+) . F_{1}$ offspring heterozygous for both $m$ and $d b$ were selected as the progenitors of future generations in which, because of the close linkage of $m$ and $d b$, only three genotypes are produced. These are fat black mice homozygous for $d b(d b+/ d b+)$, lean black mice heterozygous for both $d b$ and $m(+m / d b+)$, and misty mice homozygous for $m(+m /+m)$ in the ratio of $1: 2: 1$. Thus mice heterozygous for $d b$ and $m$ can be distin. guished phenotypically from diabetics and normals and used as parents of the next generation. The progression of the disease is similar in both these diabetic stocks and mice of the DBM stock were used because of their ready availability. The normal control mice for both groups came from the $\mathrm{C} 57 \mathrm{BL} / \mathrm{K}_{\mathrm{sJ}}$ inbred strain.

Both normal and diabetic mice $5-6$ weeks of age were injected intraperitoneally with GTG at a concentration of $0.8 \mathrm{mg} / \mathrm{g}$ body weight. To produce the electrolytic lesions, the head of the anesthetized mouse was firmly positioned in the mouse stereotaxic instrument (Brain Research Instruments, Hopewell, New Jersey, USA) and a direct current of 1.5 milliamperes was passed for 10 seconds through the positioned electrode (a \# 714 epilation needle, coated with plexiglass except for $0.5 \mathrm{~mm}$ at the tip, Butcher Corp., Los Angeles, California). We found bilateral lesions at the following co-ordinates; $3.8 \mathrm{~mm}$ anterior to the superior cerebellar artery (usually $0.8 \mathrm{~mm}$ posterior to bregma), $0.3 \mathrm{~mm}$ from the midline, and $5.6 \mathrm{~mm}$ deep, to produce hyperphagia and obesity most consistently.

At sacrifice these lesioned mice were injected with a lethal dose of nembutal, perfused with saline followed by Tellyesniczky's fluid, and then the heads were removed and soaked in fixative for an additional $24 \mathrm{~h}$. Each brain was then dissected free of the skull, refixed in fresh fixative overnight, and then trimmed to obtain a cross-section of the part containing the hypothalamus. The sections were dehydrated, embedded, sectioned serially at $10 \mu$, and stained with luxol fast blue and cresylechtviolet to allow visualization of the lesioned area.

Blood sugar concentrations and weights were determined weekly. Plasma insulin concentrations were determined 8 to 10 weeks after treatment or at the time of sacrifice. All observations reported here deal with the period up to 12 weeks after treatment at which time representative mice were sacrificed for histological studies of the pancreases. All chemical methods and histological staining were carried out as previously described [2].

\section{Results}

Gold thioglucose studies. Twenty-nine diabetic mice (18 males and 11 females) were treated with GTG. Of these, 18 (11 males and 7 females) survived. Of 30 normal mice treated, 16 survived and became hyperphagic with resultant obesity. Thirteen diabetic mice of the DBM stock (8 males and 5 females) served as an untreated diabetic control population. Fig. 1 a compares the rate of weight gain in male mice of the three groups. Although the average weight of the treated normal mice was slightly less than that of either diabetic group, no differences in rates of weight gain were observed.

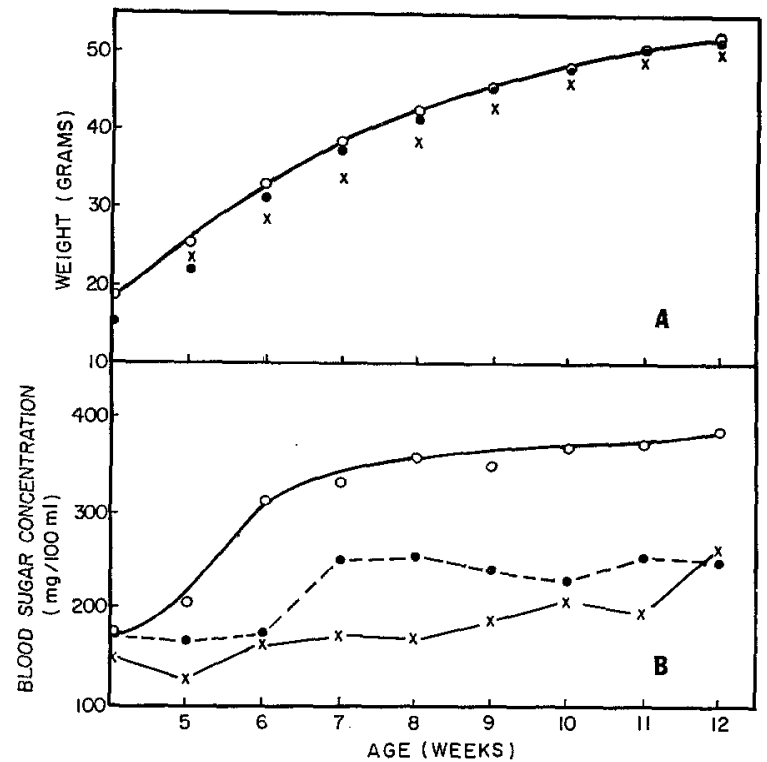

Fig. 1. Curves of weight (A) and blood sugar concentration changes $(B)$ with increasing age in untreated diabetic $(0-0)$, GTG treated diabetic (- - o ), and treated normal $(x-x)$ mice. The diabetic mice represented were all males of the DBM stock, whereas the normal mice were males of the C57BL/KsJ strain

Fig. $1 \mathrm{~b}$ shows the changes in blood sugar concentration in these same groups of male mice with advaneing age. Whereas the average normal value for untreated control mice (not shown) remained at about $150 \mathrm{mg} / 100 \mathrm{ml}$ during this age period, that for untreated diabetic male mice of the DBM stock increased to an average value approaching $400 \mathrm{mg} / 100 \mathrm{ml}$ between 
9 and 12 weeks of age. In contrast those diabetic mice treated with GTG did not show nearly as rapid an increase and did not attain an average value over $250 \mathrm{mg} /$ $100 \mathrm{ml}$. Two mice of this treated group of males had blood sugar concentrations very similar to those seen for the untreated diabetic control group. If these mice, which were apparently unresponsive to GTG are excluded, the average blood sugar value for the GTG treated diabetics would not have exceeded $200 \mathrm{mg} /$ $100 \mathrm{ml}$, a value very similar to the slight hyperglycemia observed in GTG treated normal mice (Fig. 1b).

Plasma immunoreactive insulin at 11 and 13 weeks of age averaged $483 \pm 93 \mu \mathrm{U} / \mathrm{ml}$ for untreated diabetic mice (both males and females) compared with $1360 \pm$ $1000 \mu \mathrm{U} / \mathrm{ml}$ for GTG treated diabetic mice and $688 \pm$ $85 \mu \mathrm{U} / \mathrm{ml}$ for GTG treated normal mice. The value for treated normal mice is markedly higher than that found in normal untreated mice $(71.3 \pm 4.8 \mu \mathrm{U} / \mathrm{ml})$ of the same age.

Eight ( 5 male and 3 female) GTG treated diabetic ( $d b / d b)$ mice and seven (4 male and 3 female) GTG treated normal $(+/+)$ mice were sacrificed at 11 to 14 weeks of age, 7 to 10 weeks after treatment, for histological examination of the islets of Langerhans. The islets of untreated diabetic mice of this age are not appreciably increased in number and size over normal, contain few fully granulated $\beta$-cells, and are just beginning to show the degenerative changes such as loss of clear boundaries and penetration of dilated ducts which are characteristic of islets of diabetic mice 15 weeks and older [2]. In contrast, the islets of all treated mice were not only increased in number, but many were hypertrophied. Beta cells tended to be slightly degranulated although the degree varied with individuals and their plasma concentrations of insulin. In general, the $8 \mathrm{GTG}$ treated diabetics (average plasma insulin =$981 \mu \mathrm{U} / \mathrm{ml}$ ) had more islets of all sizes, more hypertrophied islets, and more islets with a greater degree of $\beta$-cell degranulation than did the 7 treated controls (average plasma insulin $=555 \mu \mathrm{U} / \mathrm{ml}$ ). If rated for indications of islet hyperfunction, using criteria such as islet hypertrophy, blood vessel dilation and congestion, and $\beta$-cell degranulation, the decreasing order would be: treated $d b / d b$ males, treated $+1+$ males, treated $d b / d b$ females, and treated $+1+$ females. In no islets were any of the early degenerative changes seen.

Lesioning studies. Eighty-seven normal mice 8 to 10 weeks of age were lesioned. Of these, only 39 survived the first $24 \mathrm{~h}$ and only 35 survived the first week. Of the survivors, only 20 developed hyperphagia and resultant obesity. The reasons for this high mortality rate are unclear. Necropsy revealed lesions in approximately the same area of the hypothalamus in survivors and in those that died. Bleeding from the sagittal sinus was observed in some instances but this also had occurred in some of the survivors. In contrast, 14 of 15 lesioned diabetic mice survived and all responded to the treatment. The one diabetic mouse that did not survive was severely diabetic when lesioned, with a blood sugar concentration of $430 \mathrm{mg} / 100 \mathrm{ml}$, a value much higher than the average initial blood sugar concentration of the other 14 survivors (Fig. 2).

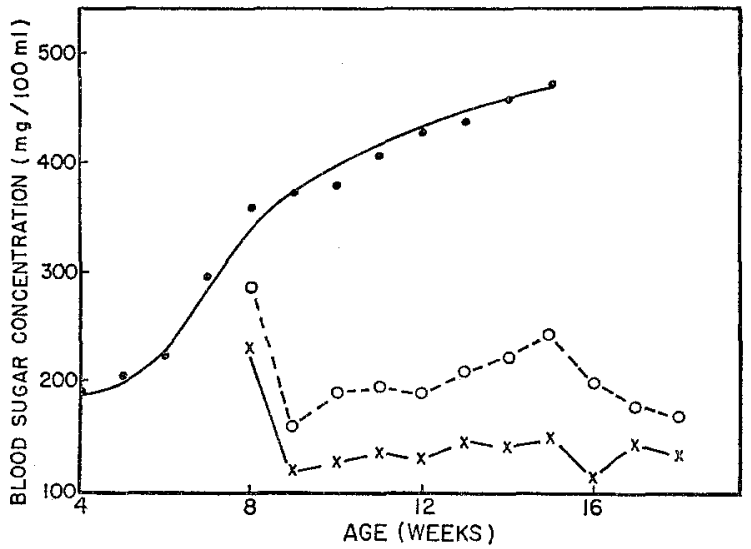

Fig. 2. Curves showing changes in blood sugar concentration with age in untreated diabetic female mice (-) lesioned diabetic female mice $(\times-\times)$, and lesioned diabetic male mice $(\mathrm{O} \longrightarrow \mathrm{O})$. The diabetic mice represented were from the $\mathrm{C} 57 \mathrm{BL} / \mathrm{KsJ}-d b$ strain

The rate of weight gain in the lesioned diabetic mice was similar to that shown in Fig. 1 a for the GTG treated and untreated diabetics. Weight gain in the lesioned normal mice was in general like that seen in GTG treated normal mice except that it was more variable. Some mice with insatiable appetites reached a weight of over $60 \mathrm{~g}$ in the 10 weeks following lesioning, whereas others included in the hyperphagic group had a more moderate rate of weight gain reaching a maximum of $50 \mathrm{~g}$ in the same period.

The development of hyperglycemia in similarly-aged control diabetics compared with lesioned diabetics is shown in Fig. 2. The average blood sugar concentration in control male diabetic mice rapidly increased to above $400 \mathrm{mg} / 100 \mathrm{ml}$, whereas in lesioned diabetic mice of both sexes the initial response was a decrease in blood sugar concentration to normal or slightly below normal levels. The average blood sugar concentration increased in lesioned male diabetic mice to mildly hyperglycemic levels 7 weeks after surgery and then decreased to near normal average values. Lesioned diabetic female mice remained euglycemic or even slightly hypoglycemic for the duration of the study. The blood sugar concentrations of the lesioned normal controls dropped after lesioning to an average value which was slightly hypoglycemic $(113 \mathrm{mg} / 100 \mathrm{ml})$ in spite of the greatly increased food consumption of these mice. Moderate hypoglycemia in the lesioned normal mice persisted throughout the experimental period.

Plasma insulin concentrations of the lesioned normal and diabetic mice compared with untreated controls are shown in the Table. Direct comparison of these data is difficult since the plasma insulin concentra. tions in untreated diabetic mice depend on parameters such as stage of disease, degree of hyperglycemia, and 
age of the mouse $[2,3]$. In general, plasma insulin is moderately elevated in the very youngest $(3-4$ weeks) diabetic mice, becomes markedly elevated with increasing blood sugar concentration and age, and then drops after the blood sugar concentration stabilizes between 400 and $500 \mathrm{mg} / 100 \mathrm{ml}$. The plasma insulin level in lesioned normal mice is increased to about double that in control mice. Lesioning of male diabetic

Table. Plasma insulin concentration in lesioned diabetic and normal mice

\begin{tabular}{|c|c|c|c|}
\hline $\begin{array}{l}\text { Genotype } \\
\text { (sex) }\end{array}$ & Treatment & Age $e^{a}$ & $\begin{array}{l}\text { Plasma immu- } \\
\text { noreactive } \\
\text { insulin. }\end{array}$ \\
\hline & & weeks & $\mu \mathrm{U} / \mathrm{ml}$ \\
\hline$+1+(\delta)$ & none & $16-18$ & $72.3 \pm 4.8(10)^{\mathrm{b}}$ \\
\hline$d b / d b\left(\sigma^{7}\right)$ & or & $5-7$ & $668 \pm 60$ \\
\hline$d b / d b$ (9) & none & $5-7$ & $609 \pm 70$ \\
\hline$d b / d b(x \&$ \& $)$ & non & $16-18$ & $71.1+15 \quad$ (10) \\
\hline$+1+\left(2^{\pi} \& 0\right)$ & lesioned & $16-18$ & $142+13$ \\
\hline$d b / d b(\pi)$ & lesio & $16-18$ & $750 \mp 140$ \\
\hline$d b / d b$ (守) & lesioned & $16-18$ & $316 \pm 58$ \\
\hline
\end{tabular}

a Age at time of insulin assay.

b Figures represent average values \pm standard error of the mean. The number of mice studied is in parenthesis.

mice caused an increase in plasma insulin levels to slightly over the peak values observed in early stage untreated diabetic males, whereas lesioning of female diabetic mice caused a decrease in plasma insulin levels to about $1 / 2$ that of untreated diabetic females. Blood sugar was maintained at normal levels in spite of this marked decrease in insulin concentration. If the plasma insulin concentrations of lesioned diabetics are compared with plasma insulin concentrations in similar aged (16-18 weeks) untreated diabetics, it is seen that in lesioned diabetics the plasma insulin level remains at about 8 times the level seen in these older diabetic mice. Thus, by this criterion the lesioned diabetic mouse remains indefinitely in the early stage of the disease. Lifespan studies have not been undertaken with lesioned diabetic mice since most of these mice were sacrificed for histological examination at 18 to 20 weeks of age. At this time the mice were still gaining weight and appeared to be in good health.

Microscopic examination of the brain sections of lesioned diabetic and normal mice revealed bilateral lesions about $0.4 \mathrm{~mm}$ in diameter in the ventromedial nuclei similar to the lesions described by Mayer et al. [9]. In most cases the lesioned area included the region of the arcuate nucleus and in some cases the median eminence. In all lesioned mice, a rather significant portion of the hypothalamus was destroyed and it is difficult to ascribe the effects as due solely to the destruction of the ventromedial nuclei.

Seven ( 4 male and 3 female) of the lesioned diabetic and four ( 2 male and 2 female) of the lesioned normal mice were sacrificed for histological examination of the islets of Langerhans. These mice were 18 to 20 weeks old and had been lesioned for a period of 10 to 12 weeks.
The islets were increased in number and size, being greatly enlarged in some cases, in both groups of lesioned mice. There was little evidence of $\beta$-cell degranulation in either group in spite of the fact that $\beta$-cells of the diabetics would have been markedly degranulated at the time lesioning was performed (8 to 10 weeks of age). A slight dilation of blood vessels, indicative of hyperfunction, was observed in islets of a few of the lesioned diabetic and lesioned control mice. Loss of clear islet boundaries was noted in a few cases but not proliferation or penetration of ducts as is usually seen in diabetic mice of this age.

\section{Discussion}

Destruction of the VMN by either GTG or electrocauterization prevented the development of severe hyperglycemia and had a therapeutic effect in those diabetic mice with already established, but moderate, hyperglycemia even though hyperphagia and the rapid accumulation of adipose tissue persisted.

Plasma insulin concentration in GTG treated diabetic mice increased to a level 3-fold higher than that in untreated diabetic mice and plasma insulin in GTG treated normal mice increased to a level 9-fold higher than that typical of untreated normal mice. These data suggest that destruction of the VIMN with gold thioglucose enhances the rate of insulin secretion in both normal and diabetic mice. Concomitant with the increased plasma insulin concentration, a tendency to hyperglycemia was observed in treated normal mice which may have been related to the strain of mice used. Hyperglycemia is not consistently found in normal mice of other strains treated with gold thioglucose [8]. The elevated plasma insulin concentration observed in GTG treated diabetic mice was sufficient to prevent the development of hyperglycemia typical of untreated diabetic mice. Although the data presented here are for only 10 weeks after treatment, the high level of plasma insulin and near normal blood sugar concentration persisted indefinitely, long past the age when diabetic mice are characterized by depleted insulin supplies in the pancreas, low plasma insulin concentration, and hyperglycemia greater than $400 \mathrm{mg} /$ $100 \mathrm{ml}[2,3]$.

Electrolytic lesioning of the VMN of diabetic mice produced results similar to those in diabetics treated with GTG in that blood sugar concentrations decreased to normal and remained normal indefinitely. However, in contrast to GTG treated diabetic mice the plasma insulin concentrations in male diabetic mice lesioned at 8 weeks were only slightly elevated compared with untreated male diabetic mice of 5 to 7 weeks of age, and the insulin concentrations in lesioned female mice were decreased to an average value about $1 / 2$ that found in untreated diabetic female mice. Maintenance of normal, rather than typically elevated, blood sugar concentrations in the presence of plasma insulin concentrations either equal to or below that normally present in diabetic mice suggests that the same concentra- 
tion of insulin is more effective in lesioned diabetic mice.

Regranulation of $\beta$-cells of the endocrine pancreas was associated with the maintenance of blood sugar at normal concentrations. Granulation of $\beta$-cells ranged from normal to slightly degranulated and the overall picture was one of hypertrophied islets with no evidence of the degenerative changes typical of untreated older diabetic mice $[2,3]$. A therapeutic effect of the lesioning on the disease appears to be confirmed by the regranulation of the $\beta$-cells of the islets of Langerhans.

Plasma insulin was increased in normal mice with electrolytic lesions but not as much as was observed in GTG treated normal mice. No tendency to hyperglycemia was observed in lesioned normal mice but in stead the average blood sugar concentration $(115 \mathrm{mg} /$ $100 \mathrm{ml}$ ) remained slightly hypoglycemic, suggesting that the circulating insulin was probably as effective as in normal mice and that the increase in insulin concentration was only proportional to the increased mass of adipose tissue.

Destruction of the satiety centers by either treatment had a therapeutic effect on the subsequent development of the diabetes and in many instances shifted the blood sugar concentration to that characteristic of similarly treated controls. These data lend support to our suggestion that the primary defect in diabetic mice may involve a defective hypothalamus. Apparently lesioning caused destruction of abnormal as well as normal functioning portions of the VMN, thereby allowing the diabetic mouse to remain in a typical hy. perphagic state but with few diabetic symptoms.

However, other explanations are equally plausible. Destruction of the VMN by either method is not specific for the satiety centers but also affects other regions. This was especially true with electrolytic lesions which, because of slight variations in head and brain size, often extended into the regions of the arcuate nucleus and median eminence. The destruction of the latter would prevent releasing factors from reaching the pituitary, thereby curtailing or eliminating the release of most anterior pituitary hormones. Since growth hormone decreases the activity of insulin in promoting glucose utilization, any decrease in its release would enhance the effectiveness of the available insulin. This insulin-sparing effect could be sufficiently large to permit the pancreas to keep up with the higher than normal demand for insulin, thereby, preventing the typical $\beta$-cell degranulation. The increased plasma insulin concentration observed in some lesioned diabetic mice and all lesioned normal mice when compared to untreated controls may result from increased insulin secretion arising from the over-activity of the ven- trolaterai nuclei once the inhibitory action of the VMN is removed. Any increased insulin secretion produced by this mechanism in diabetic mice would aid in maintaining blood sugar concentrations at normal levels and preclude the deterioration of the pancreatic islets.

The differences observed in the blood sugar and plasma insulin concentrations in GTG treated normal mice and the normal mice with electrolytic lesions may be related to the functional states of the pituitaries. A functional pituitary is a prerequisite for the development of obesity after treatment with GTG [10]. In contrast, studies with electrolytic lesions in weanling rats have shown that obesity is produced but overall growth is impaired. [5, 6, 7], implying that electrolytic lesioning impairs anterior pituitary function. Therefore, our observation of moderate to severe insulin resistance in GTG treated mice may be a consequence of either normal or greater than normal output of growth hormone, while the lack of insulin resistance in electrolytically lesioned mice may reflect their diminished output of growth hormone.

\section{References}

1. Albert, D.S., Storlien, L.H. : Hyperphagia in rats with cuts between the ventromedial and lateral hypothalamus. Science 165, 599-600 (1969).

2. Coleman, D.I., Hummel, K.P.: Studies with the mutation, diabetes, in the mouse. Diabetologia $\mathbf{3}$, $238-248$ (1967).

3. - - The mutation, diabetes in the mouse. Proc. Congr. Intern. Diabetes Fed. VIth Stockholm p. $813-820(1968)$.

4. - - Effects of parabiosis of normal with genetically diabetic mice. Amer. J. Physiol. 217, 1298-1304 (1969)

5. Frohman, L.A., Bernardis, L.L.: Growth hormone and insulin levels in weanling rats with ventromedial hypothalamic lesions. Endocrinology 82, 1125-1132 (1968).

6. - - Schnatz, J.D., Burek, L.: Plasma insulin and triglyceride levels after hypothalamic lesions in weanling rats. Amer. J. Physiol. 216, 1496-1501 (1969).

7. Han, P.W., Lui, A.C.: Obesity and impaired growth of rats force fed 40 days after hypothalamic lesions. Amer. J. Physiol. 211, 229-231 (1966).

8. Malaisse, W.J., Malaisse-Lagae, F., Coleman, D.L.: Insulin secretion in experimental obesity. Metabolism 17, 802-807 (1968).

9. Mayer, J., French, R.G., Zighera, C.F., Barrnett, R.J.: Hypothalamic obesity in the mouse. Production, description, and metabolic characteristics. Aroer. J. Physiol. 182, 75-82 (1955).

10. Redding, T.W., Bowers, C.Y., Schally, A.V.: Effects of hypophysectomy on. hypothalamic obesity in CBA mice. Proc. Soc. exp. Biol. 121, 726 - 729 (1966).

D. L. Coleman, Ph. D.

The Jackson Laboratory

Bar Harbor, Maine 04609, USA 